\title{
Responsible Consumer Behavior: Driving Factors of Pro-Environmental Behavior toward Post-Consumption Plastic Packaging
}

\author{
Widayat Widayat ${ }^{1, * \mathbb{D}}$, Ardik Praharjo ${ }^{1}$, Viajeng Purnama Putri ${ }^{1}$, Sri Nastiti Andharini ${ }^{1}$ and Ilyas Masudin ${ }^{2} \mathbb{D}$ \\ 1 Faculty of Economics and Business, University of Muhammadiyah Malang, Malang 65145, Indonesia; \\ ardikpraharjo@umm.ac.id (A.P.); viajengputri@umm.ac.id (V.P.P.); nastiti@umm.ac.id (S.N.A.) \\ 2 Industrial Engineering Department, University of Muhammadiyah Malang, Malang 65144, Indonesia; \\ masudin@umm.ac.id \\ * Correspondence: widayat@umm.ac.id
}

Citation: Widayat, W.; Praharjo, A.; Putri, V.P.; Andharini, S.N.; Masudin, I. Responsible Consumer Behavior: Driving Factors of Pro-Environmental Behavior toward Post-Consumption Plastic Packaging. Sustainability 2022, 14, 425. https://doi.org/10.3390/ su14010425

Academic Editors: Baojie He, Ayyoob Sharifi, Chi Feng and Jun Yang

Received: 30 November 2021 Accepted: 24 December 2021 Published: 31 December 2021

Publisher's Note: MDPI stays neutral with regard to jurisdictional claims in published maps and institutional affiliations.

Copyright: () 2021 by the authors Licensee MDPI, Basel, Switzerland. This article is an open access article distributed under the terms and conditions of the Creative Commons Attribution (CC BY) license (https:// creativecommons.org/licenses/by/ $4.0 /)$.

\begin{abstract}
This quantitative investigation aims to test the model of responsible consumption behavior (RCB). The specific purpose is to examine the relationship of pro-environmental behavior, attitudes, norms, intention, and awareness using the theory of planned behavior as an underlying theoretical framework. A multistage sampling technique was used to select people $(n=665)$. Data were collected using a self-administered questionnaire from sample respondents. The data were analyzed using structural equation modeling (SEM)-partial least square (PLS). The findings revealed that attitudes, norms, and awareness all have a role in predicting the intention to engage in post-consumer plastic packaging activity. This finding supports the theory of planned behavior, and it can be extended to explain environmental behavior by adding a reasonable variable.
\end{abstract}

Keywords: awareness; attitude; social norm; responsible behavior; plastics; post-consumption

\section{Introduction}

Environmental pollution by plastic waste is an interesting problem that has not been satisfactorily resolved until recently [1]; it has become a fascinating topic. This issue is becoming increasingly attractive, exacerbated by the proliferation of products packaged with plastic materials, and has become an inseparable part of business life. Products for daily use with plastic packaging are widely circulated in the community [1-3]. Various goods, beverages, food, cosmetics, and other items are packaged using plastic and distributed among the community [4]. The increased consumption of products packaged in plastic bottles, bags, etc., is causing an environmental problem. Plastic packaging products offer a variety of positive benefits. They can be attractive, lightweight, practical, and easy to carry around everywhere, but they have a negative long-term impact. Additionally, despite being difficult to decompose, plastic packaging products that have expired contribute significantly to polluting soil, water, and even the ocean [5].

An essential agent in the problem of plastic pollution is the consumer. Understanding consumers' purchasing decisions may contribute to solving the issue of plastics. Their attitude toward product packaging that has reached the end of its useful life, especially product packaging made of plastic pollutants, is a critical issue that needs attention [4,6-8]. Ideally, a consumer has a responsibility toward the environment, but the number of environmentally conscious consumers who act appropriately toward the environment is negligible. They are partly aware of plastic pollution, but their behavior is still not proenvironmental $[9,10]$. Therefore, post-consumption behavior related to plastics use is an exciting topic for research [11,12]. Understanding the antecedents that influence consumer action toward the packaging of products they use is a fascinating topic [13]. The consumer's role as a central agent in environmental pollution issues is the same as that of a person 
with a high level of responsibility. Consumers are the main actors who act as responsible parties for making welfare the long-term goal of consumption. Therefore, understanding the issue before purchasing environmentally friendly products is critical. However, it is also necessary to understand their behavior after consuming products packaged with potentially polluting materials, such as plastic. Consumer behavior in dealing with product packaging waste can be used to study how to solve the problem of environmental pollution caused by plastic waste.

So far, most of the empirical evidence has examined the antecedents that influence consumer behavior related to post-purchase behavior. However, the survey of post-purchase consumer actions is more focused on general marketing frameworks that examine the antecedents that influence consumer behavior in considering or buying green products or services [14], but it has forgotten the goal of improving consumer welfare [15]. Furthermore, the theoretical foundation has gaps that allow it to be expanded. The theory of planned behavior (TPB), introduced by Azjen, is a well-known and widely used theory that has been applied to explain environmental pollution in different contexts [16]. The essential components of TPB comprise behavior, intentions, attitudes, and norms. Attitudes and norms are closed predictors of intention, and intention explains the behavior. In this framework, it was the aim of an intervening variable to bridge attitudes and first-order norms toward behavior [17-21]. Although it is widely used as a foundation for research in various contexts, this framework has the potential to be expanded. One of the existing gaps is the fact that the framework is based on the actors' internal factors.

Based on TPB, several studies have been conducted on environmental issues. For instance, Wang et al. [22] examined consumers' intention in China's green hotel industry. However, the impact of environmental concern on the intention of consumers to visit green hotels is relatively limited, and the subjective norm has a strong effect. Meanwhile, the research of Shin et al. [23] indicated that attitude, subjective norm, perceived behavioral control, and personal norm are determinants of intention. Another relevant study, on the use of single-use plastic bags [19], analyzes whether the environmental profile of park visitors influences their willingness to pay for park conservation [24]. Other researchers who have tried to apply TPB and its expansion to ecological issues or green behavior include Li et al. [25] and Savari and Gharechaee [26].

Awareness is one's consciousness of things [27-30], and it influences a person's attitude and behavior. For instance, in the context of pro-environment research, Praneetham et al. [31] examined the relationship between environmental knowledge, attitudes, and behaviors and the management of historical tourism resources. Consequently, awareness has a favorable association with ecological attitudes and behaviors and the management of historical tourist resources and environmental attitudes and behaviors. Furthermore, Rogayan Jr. and Elyionna [32] discovered a moderate association between students' awareness of ecological concepts and issues and their behaviors in solving environmental problems and a high level of commitment. However, there has been very little research that correlates consumer awareness to intentions and behavior in the context of post-consumption relating to plastic product packaging. Therefore, this paper examines awareness as an antecedent variable that influences behavior. Apart from this condition, it is very logical and rational for the authors to continue investigating awareness in the context of consumer behavior in post-consumption concerning plastic packaging.

An intriguing topic being researched is the impact of attitudes, norms, and awareness on pro-environmental intentions and behavior (ProEnv Behavior). Thus, the purpose of this article is to explore the structural model of how attitude variables, norms, and awareness contribute to intention and ultimately to pro-environmental behavior. This article is organized systematically to make it easy for the reader to follow, beginning with an introduction that explains why this topic is interesting, then moving on to a literature review, research methodologies, results, and discussion. Finally, at the end of this article, we summarize the study's implications and limitations. 


\section{Literature Review}

\subsection{Pro-Environmental Behavior}

This research focuses on pro-environmental behavior. Ecological publications often use the term "pro-environmental". The word denotes a state, action, attitude, or knowledge that pays attention, cares, and is willing to safeguard the planet from contamination from numerous objects. Otherwise, pro-environmental behavior refers to people's decisions to accept and utilize modern and clean technologies in their agricultural methods in order to protect the environment $[29,30]$. The term pro-environment is often used with different names but has the same meaning. Some authors use "pro-environment" [17,31-37], while others use "environmentally friendly" [38,39], and some call it "green", "green consumption", or "green behavior" $[40,41]$. In the context of behavior, it can take the form of consuming or choosing environmentally friendly products to limit car use and conserve energy. The meaning is the behavior or actions taken by consumers in relation to product packaging after they have finished with the product. For example, post-purchase responsible consumption includes material separation after usage, donating, sharing, or conserving objects for reuse instead of purchasing another one, where the consumer habitually considers personal, environmental, and social benefits [42].

\subsection{Attitude, Intention, and Pro-Environmental Behavior}

In current research, the most prevalent definition of the notion of attitude is an internal psychological inclination represented by a favorable or unfavorable judgment of some entity. The reports were extensive in scope, including cognitive, emotional, motivational, and behavioral aspects. First and foremost, an attitude is a cognitive judgment of an object. Anything can be an attitude object. Most researchers agree on these core definitions, but more elaborate models of the attitude concept vary considerably [43]. Second, attitude is the degree to which a person makes a favorable or unfavorable evaluation of the behavior in question. Third, attitudes concern aspects of the individual's world, such as another person, a physical object, a behavior, or a policy $[16,44]$. Finally, attitude is a mental or neural state of readiness, organized through experience, exerting a direct or dynamic influence on the individual's response to all objects and situations related to it. Fourth, it is a complicated and multidimensional concept, which includes negative and positive senses of the environment and a mental state that affects people's climate-related decisions [29]. Fifth, attitude is the subtotal of man's inclinations and feelings, prejudices and biases, and conceived notions, ideas, fears, convictions, and threats [25].

In theory, attitude can influence behavior. The basic approach used to test the influence of attitude on behavior, commonly known as the theory of planned behavior (TPB), was introduced by Itjek Azen in 1991. The theory explains that the closest variable, namely intention, generally defines behavior. The choice is an antecedent that is influenced by subjective attitudes and norms. TPB, a theory often applied in explaining behavioral problems, is a scientific basis for various social studies. The basic model for this theory consists of behavior, intentions, attitudes, and subjective norms [16,45-48]. Consider three types of belief to guide human behavior: behavioral, normative (subjective norms), and control. This theory incorporates attitudes toward behavior, subjective norms, and behavioral management. Attitude toward behavior is a person's willingness to like or dislike a type of behavior.

Many previous studies have addressed the TPB in relation to social, health, and environmental issues, predicting environmentally friendly demeanor, and so on. For example, Saleki and Seyedsaleki [49] apply the TPB to study purchase behavior in relation to organic products in Malaysia; Hackman and Knowlden [50] use it in relation to dietary-based behavior interventions; Shah Alam and Mohamed Sayuti [51] extend prior research by examining halal food purchasing behavior in Malaysia; Paul et al. [52] investigate the issue of consumption of green products. In addition, some researchers such as Paul et al. [52], Record et al. [53], and Si et al. [12] extend and apply the TPB in order to incorporate environmental concerns. Other research includes Vina [21], who applies the TPB to explain single 
plastics bag usage, and Wang et al. [54], who explore factors influencing the ecological behavior of farmers in China. Based on the above, a researcher can draw from these studies in terms of the consistency of the relationship between behavioral variables associated with attitudes, intentions, and subjective norms in several relevant contexts. According to a survey of 126 articles, most scholars tend to underestimate the importance of identifying and analyzing indirect variables (beliefs) that influence behaviors. As a result, one of the theoretical underpinnings of this work is the TPB, which is enlarged to incorporate additional important ideas. Therefore, the following hypothesis states that:

\section{Hypothesis 1 (H1). Intention has a significant impact on pro-environmental behavior.}

\section{Hypothesis 2 (H2). Attitude toward plastics has a significant impact on intention.}

\subsection{Environmental Awareness-Pro-Environmental Behavior}

Awareness is a concept that indicates one's consciousness of things $[25,26]$. Awareness of something influences a person's attitude and behavior toward it. For instance, in the context of pro-environment research, a person's understanding of the need to safeguard the world from pollution and to protect the environment from waste contamination would influence that person's attitude and behavior. However, no studies have addressed such fundamental topics as those raised by Praneetham et al. [31]. Therefore, one of the goals of this study is to investigate the relationship between environmental knowledge, attitudes, and behaviors and the management of historical tourism resources.

Consequently, awareness has a favorable association with ecological attitudes and behaviors and the management of historical tourist resources and environmental attitudes and behaviors. Rogayan Jr. and Nebrida [32] discovered a moderate association between students' awareness of ecological concepts and issues and their behaviors in relation to solving environmental problems and a high level of commitment. Fu et al. [41] found that ecological concern, attitude, and knowledge indirectly impact pro-environmental behavior through behavioral intention. Furthermore, a high perceived policy efficacy makes the transition from learning to behavior easier, bridging the awareness-behavior gap. Therefore, the following hypothesis states that:

Hypothesis 3 (H3). Environmental awareness has a significant impact on pro-environmental behavior.

\subsection{Norms and Pro-Environmental Behavior}

Personal or moral norms originate in social norms or group norms. Still, they have become internalized and independently influence individual thoughts, feelings, and behavior in a social context. Individual and social norms influence human activity or behavior. Norm-activation theory proposes that pro-environmental activities occur consistently and are propelled by personal moral norms [26]. Social norm is a term that various authors often use as an independent variable that influences certain variables or as a variable that moderates the relationship of variables that are a researcher's focus. The concept of social norms differs across fields, such as psychology and economics, making interdisciplinary communication difficult. A social norm is a typical behavioral pattern within a group that is supported by a shared knowledge of appropriate behavior and maintained through social interactions [52]. Karimi [34] shows that personal norms affect pro-environmental behavior. Similarly, according to Farrow et al. [40], what other people do and how much their actions matter greatly affect individuals. Moreover, social norm dynamics can have significant implications for societal outcomes. Norms can be divided into several subcategories: First, injunctive norms convey people's ideas about what constitutes socially acceptable behavior in certain situations [53-55]. Second, a concept rooted in social identity, feelings of affinity or affiliation toward a specific social group, is referred to as group identification $[54,55]$. Third, individuals' judgments about the prevalence of conduct among members of a referent group are considered to be descriptive norms or social norms. [54-56]. Finally, outcome 
expectations refer to individuals' assessments of the benefits of taking action relative to the costs associated with the action $[54,55]$. Therefore, the hypotheses state that:

Hypothesis $4 \mathbf{( H 4 ) . ~ N o r m s ~ h a v e ~ a ~ s i g n i f i c a n t ~ i m p a c t ~ o n ~ a w a r e n e s s . ~}$

Hypothesis 5 (H5). Norm has a significant impact on attitude.

Hypothesis 6 (H6). Norms have a significant impact on pro-environmental behavior.

Hypothesis 7 (H7). Norms have a significant impact on intention.

Based on relevant previous research and existing fundamental theories, a conceptual framework in this paper can be drawn, as shown in Figure 1.

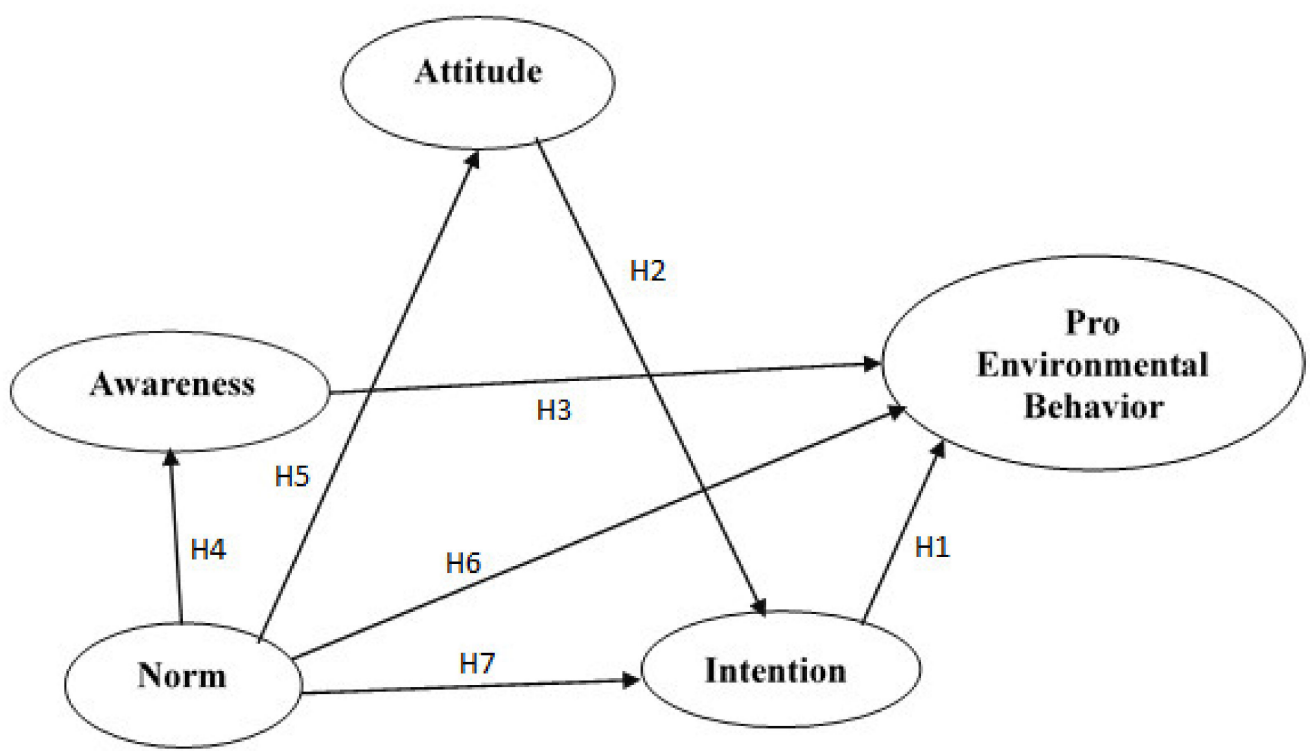

Figure 1. Conceptual framework.

\section{Methods}

\subsection{Design and Approach}

This research was designed to test a comprehensive understanding of a pro-environment consumer behavior model that elaborates the TPB using a survey-type quantitative approach. More specifically, this study aims to examine the effect of several latent independent, intervening variables, and dependent variables. The independent variables include attitude, norms, and awareness. In addition, the role of attitude toward the environment is an intervening variable, while pro-environmental behavior is a dependent variable.

\subsection{Population and Samples}

The population in this research is consumers who live in Indonesia. The researcher selected respondent samples from a specific area in several stages: (1) determining location, city/district sample area chosen at random; (2) randomly selected respondents from the consumer community lived in the selected city/district target area. The provinces and districts designated as respondents' targets were determined intentionally based on specific considerations. The respondents were randomly chosen, starting with five districts/cities (Probolinggo, Mojokerto, Gresik, Malang district, and Sidoarjo). Then, one smaller area, generally referred to as a sub-district, was picked from these locations. Finally, one subdistrict or village was chosen as the smallest research area from the sub-districts selected. In total, 100-150 residents from each village/ward were chosen as respondents. The sample used was 700 respondents, determined by considering practice, power, and precision, using 
the basis of effect size (0.1), power (0.9), number of latent variables, probability of greeting $(5 \%)$, and number of observable variables.

\subsection{Data Collection and Variables}

Data were collected using a self-administered questionnaire created by the authors and based on a selected paper. The questionnaire was distributed to employees with an enumerator in each city area. The sample respondents were given a questionnaire free of study ethics concerning human subjects. At the beginning of the questionnaire, there is an informed consent (IC). In addition, when conducting research, questionnaires should always be accompanied by a document from a university research institute confirming ethical clearance. The questionnaire used was tested for validity and reliability. The instrument items that are valid and used to collect data on each latent variable contain accurate items with a confirmatory factor analysis (CFA) weight value of at least 0.50 , with a significant correlation coefficient at $5 \%$ alpha. The reliability of the instrument was tested by using Cronbach's alpha. The device used has a Cronbach's alpha value of at least 0.60 . The variables and indicators that make up each latent variable are shown in Table 1.

Table 1. Variables and indicators.

\begin{tabular}{|c|c|}
\hline Variable and Definition & Indicator Description (Item Codes) \\
\hline $\begin{array}{l}\text { Attitude toward the environment: complicated and } \\
\text { multidimensional concept including negative and } \\
\text { positive senses of the environment and a mental state, } \\
\text { which affects consumer's actions related to plastic } \\
\text { packaging }[16,27,38,57,58]\end{array}$ & $\begin{array}{l}\text { - Handling pollution wisely (Attd10) } \\
\text { - Taking care of pollution responsibly (Attd11) } \\
\text { - } \quad \text { Keeping pollution away helps solve the problem (Attd12) } \\
\text { - } \quad \text { Managing plastic waste, actions that help protect the earth from decay (Attd13) } \\
\text { - } \quad \text { Managing waste, a good deed to keep the land alive (Attd14) } \\
\text { Protect the world and the environment from plastic waste pollution, useful in } \\
\text { - } \quad \text { Managing plastic waste can bring various benefits to your life (Attd16) } \\
\text { Disposing of plastic waste in the right place is a wise and responsible act (Attd18) }\end{array}$ \\
\hline $\begin{array}{l}\text { Awareness: consumer's awareness level of adverse } \\
\text { effects of their activities related to plastics }[17,27,31]\end{array}$ & $\begin{array}{l}\text { - Plastic irritates the respiratory tract (Awareness3) } \\
\text { - } \quad \text { Plastic can transmit disease (Awareness4) } \\
\text { - } \quad \text { Plastic contains toxic chemicals (Awareness5) } \\
\text { - } \quad \text { Plastic is carcinogenic (Awareness6) } \\
\text { - } \quad \text { Plastic releases harmful gases (Awareness7) }\end{array}$ \\
\hline $\begin{array}{l}\text { Pro-environmental behavior: actions conducted by a } \\
\text { consumer in relation to product packaging comprised } \\
\text { of expired plastic materials }[17,27,38,58]\end{array}$ & $\begin{array}{l}\text { - Asking for a special plate when eating out (Behavior09) } \\
\text { - When the shop refuses if the vessel is plastic (Behavior10) } \\
\text { - Everyday separating of plastic waste (Behavior12) } \\
\text { - Avoid plastic bags when shopping at the grocery store (Behavior13) }\end{array}$ \\
\hline $\begin{array}{l}\text { Intention: consumer's intention to take action against } \\
\text { expired plastic goods packaging in the future [58-61] }\end{array}$ & $\begin{array}{ll}\text { - } & \text { Managing waste well in the future (Intention1) } \\
\text { - } & \text { Sorting out future trash (Intention2) } \\
\text { - } & \text { Discard it in the right place (Intention3) } \\
\text { - } & \text { Sorting plastic with others (Intention4) } \\
\end{array}$ \\
\hline $\begin{array}{l}\text { Norm: perception of social pressures and expectations to } \\
\text { perform pro-environmental behaviors related to post-use } \\
\text { plastics packaging }[17,38,41]\end{array}$ & $\begin{array}{l}\text { - Indiscriminately throwing away garbage is not a problem for the surrounding } \\
\text { - } \\
\text { - } \quad \text { People take care of the environment (Norm02) } \\
\text { - The surrounding community is looked after (Norm03) } \\
\text { - The surrounding community cares about plastic pollution (Norm04) } \\
\text { - People consider it essential to protect the environment (Norm05) } \\
\text { - People around rebuke (Norm06) } \\
\text { - Neighbors remind (Norm07) } \\
\text { - Schoolfriends care (Norm08) } \\
\text { - Family education (Norm10) } \\
\text { - Provincial government education (Norm11) } \\
\text { - } \quad \text { Education from Central Government (Norm12) } \\
\text { Instruction from Local Government (Norm13) }\end{array}$ \\
\hline
\end{tabular}

The questionnaire consists of several sections: The first contains informed consent (IC), respondents' willingness to fill out the questionnaire, and the researcher's commitment not to publish the respondent's data. In addition, there are instructions on how to fill out the questionnaire. The second section contains 16 questions regarding demographic aspects of respondents, which include name/initials, residential address, gender, age, employment status, education, and category of residence. The third section contains questions about 
facilities in a residential area, including types of waste that are often in the vicinity of the home, kinds of garbage made of everyday plastic, availability of separate trash cans for plastic and non-plastic waste, availability of trash cans, availability of plastic trash cans that accept different types of waste (plastic, organic, or recyclable and non-recyclable waste), the habit of disposing waste at home (separated or not), and collected plastic bottle waste to be sold, reused or recycled. The fourth section contains items of attitudes (10 items), awareness (7 items), intentions (6 items), and norms (12 items) using the five-point Likert scale. The fifth and final section consists of pro-environmental behavior (5 items) using a five-point scale (Never (1), Very rarely (2), Occasionally (3), Frequently (4), Always (5)).

\subsection{Data Analysis}

The data collected that met the requirements were used to build a structural model and measure each latent variable. The model development uses structural equation modeling (SEM), accessed via Smart-PLS software. The model development process goes through several essential stages, including (1) compilation of empirical, theoretical models; (2) appropriate data input; (3) testing model assumptions; (4) initial modeling; (5) model modification; (6) final model goodness-of-fit test; (7) hypothesis testing; and (8) final model interpretation.

Meanwhile, testing the hypothesis of the effect of one latent variable on another latent variable, as illustrated in the path diagram in the model in Figure 1, was carried out using the t-statistic. An alternative hypothesis (Ha) was accepted if the t-statistic was higher than the t-table, at 5\% alpha, or by comparing the significance value of the path with the alpha $(5 \%)$. If the path significance value $(p)$ was smaller than alpha $(5 \%)$, the hypothesis (Ha) was accepted. Figure 1 shows the model and path of the relationship between the hypothesized variables.

\section{Results}

\subsection{Characteristics of Respondent}

This research was carried out to collect data and process several demographic variables of respondents. We successfully collected 665 out of 700 questionnaires from respondents. Those who responded in a self-administered manner had interesting demographic characteristics. The responses collected can describe age characteristics based on the four groups, as shown in Table 2 . More than half (54.43\%) of the respondents are in the second age group (21-30 years). Age groups 3 (31-40) and 4 (40 and over) are not more than 15\% each. In terms of gender, most respondents are female (59.398\%). This condition hints at behavioral tendencies, attitudes, awareness, and intentions toward the issue of plastic packaging for a product, colored by the answers from respondents with these characteristics.

Table 2. Respondents' age group and gender.

\begin{tabular}{ccc}
\hline Age Group & Number & Percent \\
\hline $1(20$ and under $)$ & 128 & 19.25 \\
$2(21-30)$ & 362 & 54.44 \\
$3(31-40)$ & 85 & 12.78 \\
$4(40$ and over $)$ & 90 & 13.53 \\
\hline Total & 665 & 100.00 \\
\hline Gender & & \\
Female & 395 & 59.40 \\
Male & 270 & 40.60 \\
\hline Total & 665 & 100.00 \\
\hline
\end{tabular}

One of the aspects mentioned in this study is employment status. This is intended to see the respondent's social environment outside of the home. Around $40 \%$ of those polled are still students in school or in college, while most respondents are workers, such as 
lecturers or teachers, or work for specific agencies. Students interact with teachers and other student friends, and workers interact with coworkers as well as people who work for the entities for which they work. Social and institutional norms will color a person's behavior, attitudes, and awareness contingent on where they work and interact. The distribution of respondents' employment status is set out in Table 3. The nearest neighborhood has consequences for the parties involved and can influence awareness, attitudes, and behavior. The immediate environment is a social institution that affects a person's behavior. A person's attitudes and behavior are influenced by the social environment in which they live. People who live in villages, for example, have different perspectives and behaviors than those who live in cities, densely populated areas, or agricultural areas. In this study, most respondents (26.32 percent) live in densely populated residential cities, while 20.75 percent live in densely populated cities but not in residential areas. Approximately 19.85 percent of respondents live in densely populated villages. The distribution of the respondent's residence in greater detail is set out in Table 4.

Table 3. Job status of respondents.

\begin{tabular}{lcc}
\hline \multicolumn{1}{c}{ Job Status } & Number & Percentage \\
\hline Private teacher/lecturer & 43 & 6.47 \\
Housewife & 65 & 9.77 \\
Student status (student of senior high school, undergraduate, graduate) & 263 & 39.55 \\
Military/police (army/police) & 3 & 0.45 \\
Fisherman & 1 & 0.15 \\
Trader & 22 & 3.31 \\
Civil servants, non-teachers/lecturers & 21 & 3.16 \\
Employees of state-owned enterprises & 15 & 2.26 \\
Employees of private agencies & 102 & 15.34 \\
Retired employee/military & 2 & 0.30 \\
Farmer & 1 & 0.15 \\
Entrepreneur (private) & 51 & 7.67 \\
Job not listed above & 76 & 11.20 \\
\hline Total & 665 & 100.00 \\
\hline
\end{tabular}

Table 4. Respondents by place of residence.

\begin{tabular}{llcc}
\hline & \multicolumn{1}{c}{ Residence } & Number & Percentage \\
\hline 1. & $\begin{array}{l}\text { Densely populated area, where there are many goats, } \\
\text { chickens, cattle, etc. }\end{array}$ & 6 & 0.90 \\
2. & A sparsely populated area & 6 & 0.90 \\
3. & Rural areas, the majority of which are agricultural/garden & 112 & 16.84 \\
4. $\quad$ Villages, densely populated but not agricultural areas & 132 & 19.85 \\
5. & Densely populated cities, but not residential & 138 & 20.75 \\
6. & Corporate/institution official residential & 14 & 2.11 \\
7. & Densely populated residential & 175 & 26.32 \\
8. $\quad$ Well-organized housing, including a particular, elite area & 63 & 9.47 \\
9. & In addition to the options above & 19 & 2.86 \\
\hline Total & 665 & 100.00 \\
\hline
\end{tabular}

Availability of facilities at home or in the residential environment can contribute to responsible intentions and behavior toward plastic packaging products that they consume daily. The availability of separate facilities for plastic and non-plastic waste at home helps shaping consumer behavior as household members daily. Some household members have a positive attitude toward plastic waste but throw garbage in the wrong place because there are no suitable trash cans. In the context of the TPB, these facilities and infrastructure are behavioral control variables. These variables can potentially encourage people to behave or discourage them. From the available data, it is revealed that only $28.87 \%$ are provided 
with two types of trash cans in their homes. Approximately $69.17 \%$ of the trash in their homes goes into one receptacle, containing both plastic and non-plastic waste.

There is only one trash can in their house or environment for all types of waste, whether plastic or not. However, it is also possible that public consumers throw away plastic waste carelessly even though there are adequate trash bins. This can also be on a broader scale, in the consumer community environment where they live, for example, in a housing development or village. Although few are found in the environment where they live, housing, urban or even rural areas are provided with different waste bins for plastic, although they do not necessarily use it properly. Respondents' answers to the availability of separate plastic and non-plastic waste bins are presented in Table 5. The table illustrates that, for most respondents, there is only one type of trash can in their living environment. Only a small part of the residential area, $22.86 \%$, is provided with separate trash cans for plastic and non-plastic.

Table 5. Plastics and non-plastics waste facility.

\begin{tabular}{ccc}
\hline In the House & Number & Percentage \\
\hline Separated trash cans not available & 460 & 69.17 \\
Not sure & 13 & 1.96 \\
Yes, separated trash cans available & 192 & 28.87 \\
Total & 665 & 100.00 \\
\hline \multicolumn{2}{c}{ In the Residence } & \\
\hline Not sure/do not know & 42 & 6.31 \\
No, one bin for all waste & 471 & 70.83 \\
Yes, separated bin for plastics and other waste & 152 & 22.86 \\
\hline Total & 665 & 100.00 \\
\hline
\end{tabular}

Consumers cannot avoid using various types of plastic waste in their daily activities. Their activities affect the number of multiple kinds of garbage in their home. Table 6 lists the different types of waste commonly found in their living environment.

Table 6. Types of plastic waste found at home.

\begin{tabular}{cccc}
\hline No. & Category of Plastics Waste & Number & Percentage \\
\hline 1 & Automotive materials & 3 & 0.45 \\
2 & Cosmetics and body care & 6 & 0.90 \\
3 & Industrial materials & 26 & 3.92 \\
4 & Toiletries & 80 & 12.07 \\
5 & Health and medicine & 152 & 22.93 \\
6 & Drinking bottle & 156 & 23.53 \\
7 & Kitchen and other household utensils & 242 & 36.39 \\
\hline
\end{tabular}

Table 6 shows that the most common type of waste in their residential environment is the packaged kitchen and other household utensils, with a percentage of $36.39 \%$. The second and third most common plastic waste packaging materials are health, medicine, and drinking bottles. Compared to other types of waste, plastic waste for cosmetic packaging and automotive purposes is the least prevalent, not more than $1 \%$. These data show that kitchen activities such as kitchen utensils with materials packaged in plastic packaging generate a lot of plastic waste in residence. On the other hand, automotive activities, such as changing the oil in their motorcycles, cars, or other machines, are rarely undertaken at home. Many of these activities occur in workshops or stores that sell oil and other automotive tools. As a result, plastic waste packaging materials designed for automotive purposes are used sporadically in their homes. The distribution of different types of waste is shown in Table 6. 


\subsection{Outer Model Evaluation}

This research paper is designed to examine the structural model of responsible consumer behavior. The model describes the relationship between several latent variables, each measured by many indicators. The final model discussed is the modeling output, carried out in several evaluation stages. First, the evaluation of the model was carried out on the validity and reliability of the latent variable construction. As seen in Table 7, the composite reliability Cronbach's alpha value for each latent variable reaches the lowest point at 0.80 and the highest point at 0.94 , exceeding the threshold of 0.70 . Another indicator, rho_A, shows a fair value above 0.80 and composite reliability.

Table 7. Construct reliability and validity.

\begin{tabular}{ccccc}
\hline Latent Variables & $\begin{array}{c}\text { Cronbach's } \\
\text { Alpha }\end{array}$ & rho_A & $\begin{array}{c}\text { Composite } \\
\text { Reliability }\end{array}$ & $\begin{array}{c}\text { Average } \\
\text { Variance } \\
\text { Extracted (AVE) }\end{array}$ \\
\hline Attitude & 0.94 & 0.95 & 0.95 & 0.72 \\
Awareness & 0.85 & 0.86 & 0.89 & 0.53 \\
Descriptive & 0.92 & 0.93 & 0.94 & 0.65 \\
$\quad$ Norm & 0.89 & 0.89 & 0.92 & 0.64 \\
Intention & 0.93 & 0.93 & 0.94 & 0.56 \\
Norm & 0.80 & 0.81 & 0.86 & 0.56 \\
ProEnv_Behavior & 0.87 & 0.87 & 0.91 & 0.73 \\
Social Norm & & & & \\
\hline
\end{tabular}

Meanwhile, convergent validity can be seen from the average variance extracted (AVE) value. A variable can be accepted and declared valid if the AVE value is more than 0.50. Finally, the AVE value of all variables is adequate or acceptable, with the highest value of 0.73 and the lowest value of 0.53 . Considering the magnitude of these criteria, all latent variables can be declared adequate or acceptable.

Discriminant validity for each latent variable can be seen using the Fornell-Larcker criterion (FLC) and heterotrait-monotrait ratio (HTMT). These two criteria are used to detect multicollinearity in constructs. Variables are free from multicollinearity problems if the value is less than 0.80 . Table 8 show the FLC and Table 9 show HTMT for all variables. In the off-diagonal cell, there are no numbers whose values are equal to or more than 0.80 , except for the norm, descriptive norm, and social norm variables. This condition shows that there is no multicollinearity problem for all latent variables. For example, the value of FLC for the descriptive norm variable with norm is 0.95 ; for the norm variable with the social norm, it is 0.84 . This happens because the latent norm variable is measured in a second order composed of two latent variables: social norm and descriptive norm.

Table 8. Fornell-Larcker criterion (FLC).

\begin{tabular}{cccccccc}
\hline & Attitude & Awareness & Descriptive Norm & Intention & Norm & ProEnv Behavior & Social Norm \\
\hline Attitude & 0.85 & - & - & - & - & - & - \\
Awareness & 0.21 & 0.73 & - & - & - & - & - \\
Descriptive & 0.25 & 0.20 & 0.81 & - & - & - & - \\
Norm & 0.65 & 0.26 & 0.42 & 0.80 & - & - & - \\
Intention & 0.33 & 0.25 & 0.95 & 0.51 & 0.75 & 0.75 & 0.32 \\
Norm & 0.10 & 0.34 & 0.28 & 0.31 & 0.32 & 0.85 \\
ProEnv Behavior & 0.38 & 0.28 & 0.63 & 0.52 & 0.84 & 0.32 \\
Social Norm & &
\end{tabular}


Table 9. Heterotrait-monotrait ratio (HTMT).

\begin{tabular}{cccccccc}
\hline & Attitude & Awareness & Descriptive Norm & Intention & Norm & ProEnv Behavior & Social Norm \\
\hline Attitude & - & - & - & - & - & - & - \\
Awareness & 0.25 & & - & - & - & - & - \\
Descriptive & 0.28 & 0.22 & 0.47 & - & - & - & - \\
Norm & 0.71 & 0.30 & 1.03 & 0.55 & - & - & - \\
Intention & 0.35 & 0.28 & 0.32 & 0.36 & 0.37 & - & - \\
Norm & 0.13 & 0.39 & 0.70 & 0.59 & 0.93 & 0.38 & - \\
ProEnv Behavior & 0.42 & 0.32 & & - & - & - \\
Social Norm & &
\end{tabular}

The measuring items for each latent variable need to be assessed for their validity level. The validity of the latent variable measurement model in this paper is seen from the cross-loading value. The measuring indicator of a latent variable is acceptable and valid as a measure of a latent variable if the value of the cross-loading on the variable concerned is more significant and the largest among the cross-loading values for other variables. The cross-loading of each item measuring the latent variable in this paper is set out in Table 10. For instance, columns 1-7 are latent variables in the table, while the leftmost column is an indicator. In column 1, there is an indicator of attitude. It appears that the value is 0.83 for the Attd10 indicator and 0.84 for the Attd11 indicator. When compared to the loading value in the other column (2-7) to the right, the loading value in that column is the largest and most significant. This suggests that Attd10 and Attd11 are the best indicators for the attitude variable, particularly when compared to other indicators such as Attd12, Attd13, Attd14, Attd15, Attd16, and Attd18. We can evaluate the awareness, intention, norm, and behavior variables' item validity by using the same method. Items Awarns1-Awarns7 are the best measure of the awareness variable, with the highest loading when measuring other variables. Items Behav10-Behav13 are the best measures of the behavior variable, with a loading of 0.68 to 0.79 being the highest when used to measure other variables, while the intention variable mainly comprises indicators Ints1 to Ints6 with loading values ranging from 0.65 to 0.86 . The norm variable is built in the second order, with the Norm10-Norm13 items having adequate loading values ranging from 0.72 to 0.92 and Norm2-Norm 9 having loading values ranging from 0.65 to 0.82 . These useful items are measures of each latent variable in the measurement model depicted in Figures 2 and 3.

\subsection{Final Model}

Figures 2 and 3 show the construction of the measurement model, which consists of adequate indicators for each variable, and the structural model, which supplies the proposed latent variables to be tested. The measurement model and structural model are represented in both figures. The measurement model on the outside of the figure depicts the latent variable building, which consists of adequate items and has a minimum loading value of 0.50 (Figure 2) and a t-statistic value greater than 2.00 (Figure 3). The latent variable measurement is represented by a circle (blue), which is linked by an arrow to the yellow box with a loading value higher than 0.50 (Figure 2) and t-statistic higher than 2.00 (Figure 3), which is the indicator symbol. Furthermore, both figures show a structural model describing the relationship between latent variables indicated by several blue circles with arrows leading to other blue circles. The loading value (Figure 2) and $t$-statistic value are located in the center of the arrow (Figure 3).

Table 11 provides numbers representing the coefficient's amount and the direct relationship between the variable's influence and other variables. Intention (beta $=0.15 ; \mathrm{t}=3.28$ and $p=0.00$ ), awareness (beta $=0.25 ; \mathrm{t}=8.61$ and $p=0.00$ ), and norm (beta $=0.17 ; \mathrm{t}=3.51$ and $p=0.00$ ) all had substantial positive effects on pro-environmental behavior (ProEnv Behavior). The better one's environmental behavior, the higher one's awareness, support for social standards, and intentions. The coefficient value indicates the variable that has the greatest influence on behavior among the other two variables, and the t-statistic is the 
largest among the other variable coefficients. Attitudes and norms directly and significantly affect intentions, with coefficient values of 0.54 and 0.33 , respectively, and t-statistic values of $17.41(p=0.00)$ and $8.77(p=0.00)$. Each path's coefficient (original sample) is positive and has a value greater than one. This means that the predictor variables on the path have a one-way influence on the predicted variables. For instance, the intention to behave in a pro-environmental manner is equal to 0.15 . The greater a person's intention to behave pro-environmentally, the higher the value of behavior in post-consumption plastic product packaging. The greater the consumer's awareness, the greater their intention to behave in an environmentally friendly manner. The stronger the norms that apply to and encourage consumers, the greater their awareness and intention to behave in an environmentally friendly manner.

Table 10. Cross loading indicators.

\begin{tabular}{|c|c|c|c|c|c|c|c|}
\hline Item Code & Attitude & Awareness & Descriptive Norm & Intention & Norm & ProEnv Behavior & Social Norm \\
\hline Attd10 & 0.83 & 0.19 & 0.23 & 0.57 & 0.29 & 0.08 & 0.31 \\
\hline Attd11 & 0.84 & 0.18 & 0.18 & 0.51 & 0.24 & 0.08 & 0.26 \\
\hline Attd12 & 0.91 & 0.20 & 0.22 & 0.57 & 0.30 & 0.08 & 0.36 \\
\hline Attd13 & 0.92 & 0.18 & 0.23 & 0.56 & 0.31 & 0.09 & 0.35 \\
\hline Attd14 & 0.91 & 0.18 & 0.21 & 0.54 & 0.28 & 0.11 & 0.33 \\
\hline Attd15 & 0.89 & 0.18 & 0.22 & 0.57 & 0.29 & 0.08 & 0.34 \\
\hline Attd16 & 0.83 & 0.24 & 0.23 & 0.59 & 0.30 & 0.13 & 0.34 \\
\hline Attd18 & 0.67 & 0.09 & 0.19 & 0.49 & 0.24 & 0.02 & 0.28 \\
\hline Awarns1 & 0.07 & 0.69 & 0.15 & 0.16 & 0.18 & 0.31 & 0.19 \\
\hline Awarns2 & 0.10 & 0.73 & 0.17 & 0.15 & 0.21 & 0.33 & 0.22 \\
\hline Awarns3 & 0.19 & 0.74 & 0.14 & 0.19 & 0.18 & 0.22 & 0.19 \\
\hline Awarns4 & 0.22 & 0.72 & 0.15 & 0.22 & 0.20 & 0.16 & 0.24 \\
\hline Awarns5 & 0.16 & 0.76 & 0.12 & 0.18 & 0.16 & 0.24 & 0.17 \\
\hline Awarns6 & 0.21 & 0.71 & 0.12 & 0.18 & 0.16 & 0.20 & 0.19 \\
\hline Awarns7 & 0.20 & 0.75 & 0.14 & 0.25 & 0.18 & 0.20 & 0.20 \\
\hline Behav10 & -0.01 & 0.21 & 0.21 & 0.18 & 0.23 & 0.77 & 0.21 \\
\hline Behav11 & 0.06 & 0.22 & 0.25 & 0.22 & 0.27 & 0.68 & 0.24 \\
\hline Behav12 & 0.08 & 0.31 & 0.24 & 0.29 & 0.29 & 0.79 & 0.29 \\
\hline Behav13 & 0.14 & 0.28 & 0.11 & 0.23 & 0.17 & 0.75 & 0.23 \\
\hline Behav9 & 0.10 & 0.24 & 0.19 & 0.22 & 0.22 & 0.74 & 0.19 \\
\hline Ints1 & 0.53 & 0.19 & 0.32 & 0.78 & 0.38 & 0.18 & 0.39 \\
\hline Ints2 & 0.51 & 0.25 & 0.36 & 0.83 & 0.44 & 0.33 & 0.44 \\
\hline Ints3 & 0.60 & 0.21 & 0.36 & 0.86 & 0.42 & 0.25 & 0.41 \\
\hline Ints4 & 0.49 & 0.19 & 0.35 & 0.84 & 0.41 & 0.30 & 0.41 \\
\hline Ints5 & 0.53 & 0.22 & 0.35 & 0.83 & 0.44 & 0.25 & 0.49 \\
\hline Ints6 & 0.46 & 0.15 & 0.29 & 0.65 & 0.33 & 0.17 & 0.33 \\
\hline Norm10 & 0.36 & 0.26 & 0.56 & 0.48 & 0.69 & 0.34 & 0.72 \\
\hline Norm11 & 0.32 & 0.25 & 0.51 & 0.45 & 0.72 & 0.28 & 0.92 \\
\hline Norm12 & 0.32 & 0.17 & 0.53 & 0.39 & 0.70 & 0.21 & 0.85 \\
\hline Norm13 & 0.29 & 0.26 & 0.53 & 0.43 & 0.73 & 0.26 & 0.91 \\
\hline Norm2 & 0.21 & 0.17 & 0.79 & 0.32 & 0.74 & 0.21 & 0.47 \\
\hline Norm3 & 0.15 & 0.13 & 0.80 & 0.35 & 0.75 & 0.25 & 0.49 \\
\hline Norm4 & 0.18 & 0.16 & 0.87 & 0.34 & 0.81 & 0.23 & 0.51 \\
\hline Norm5 & 0.25 & 0.15 & 0.86 & 0.35 & 0.82 & 0.21 & 0.54 \\
\hline Norm6 & 0.15 & 0.15 & 0.86 & 0.31 & 0.80 & 0.20 & 0.50 \\
\hline Norm7 & 0.11 & 0.15 & 0.86 & 0.32 & 0.81 & 0.24 & 0.52 \\
\hline Norm8 & 0.23 & 0.16 & 0.75 & 0.29 & 0.73 & 0.20 & 0.51 \\
\hline Norm9 & 0.38 & 0.23 & 0.63 & 0.46 & 0.65 & 0.23 & 0.50 \\
\hline
\end{tabular}




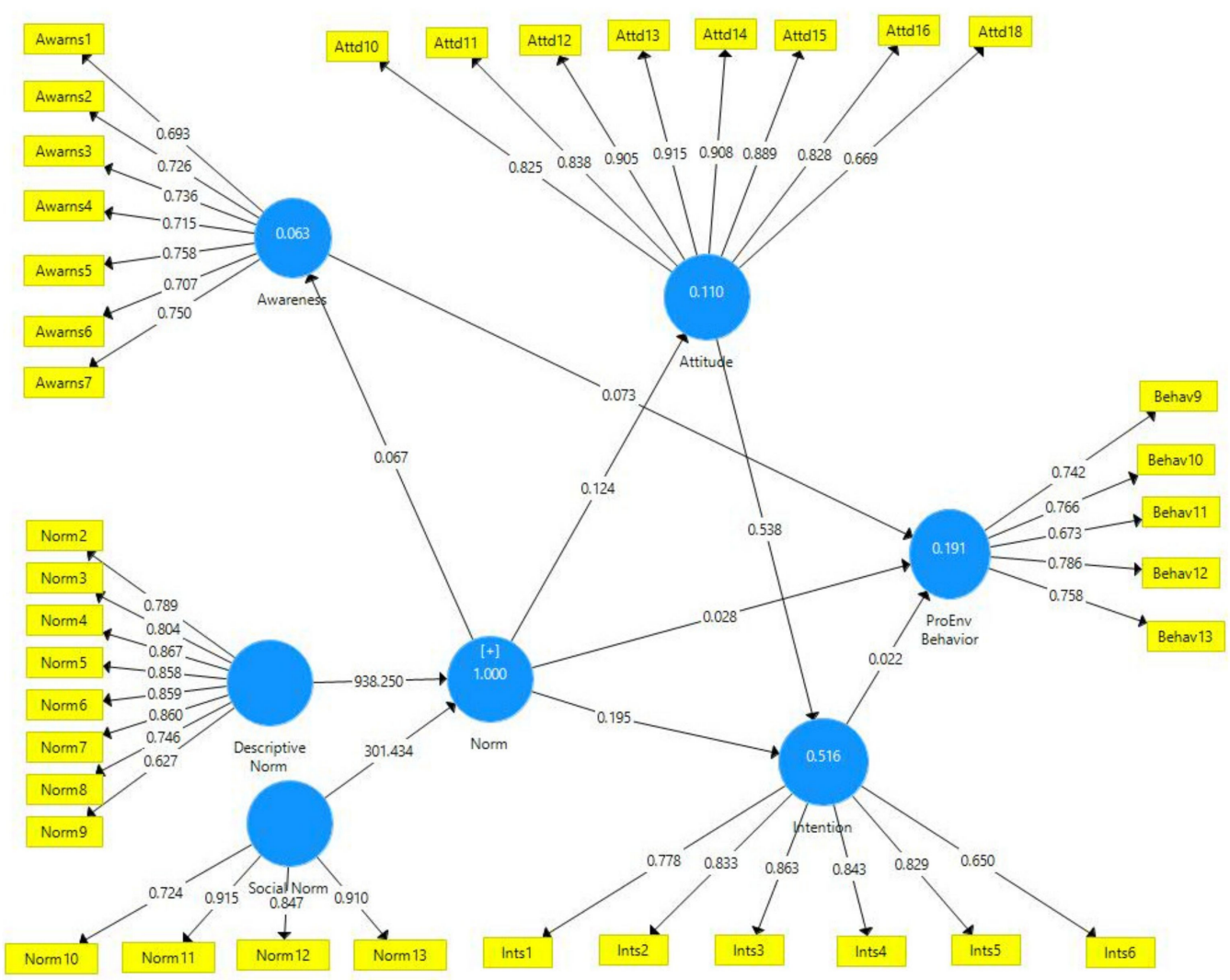

Figure 2. Measurement model and structural model of responsible consumer (with coefficient).

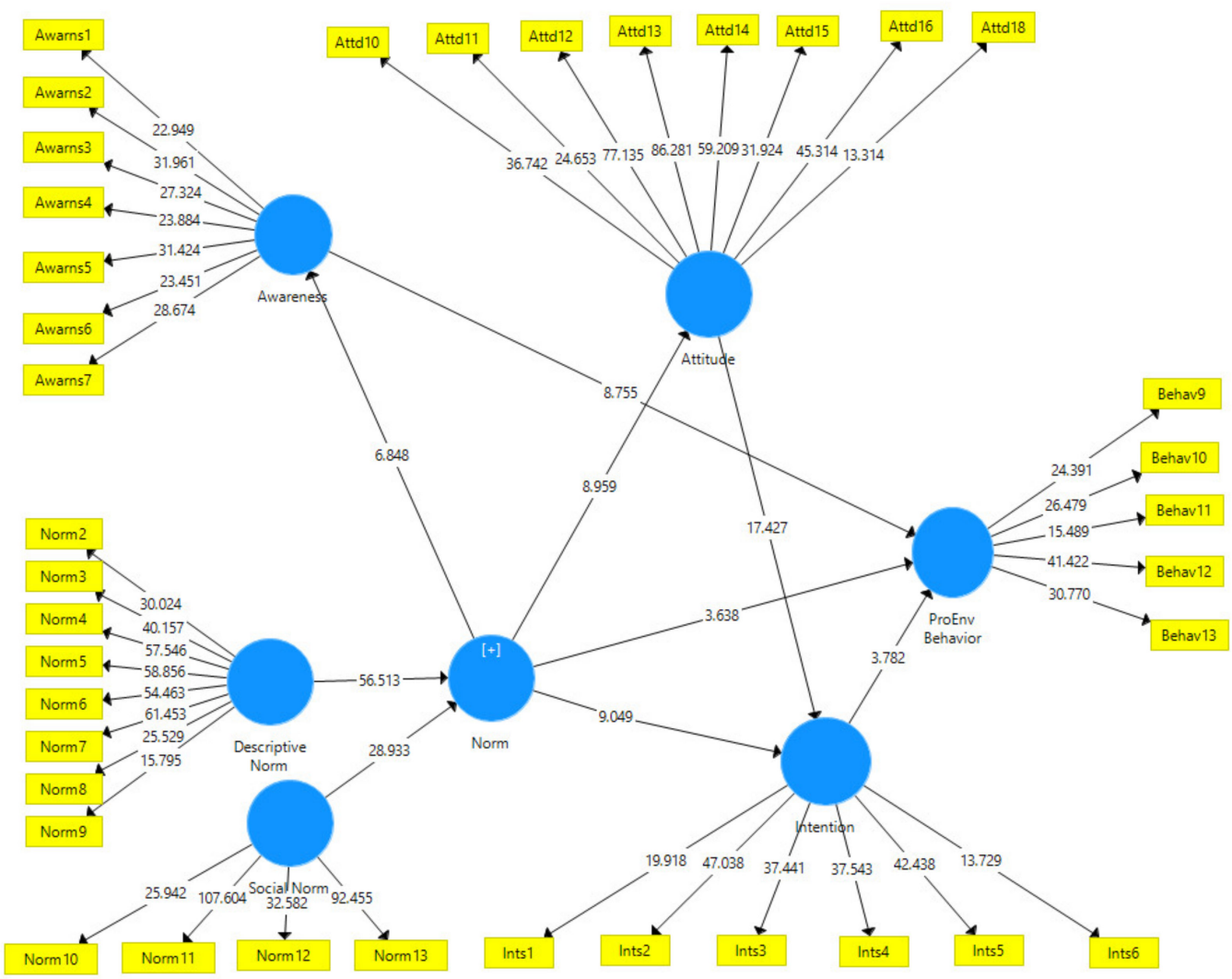

Figure 3. Measurement model and structural model of responsible consumer (with t-statistic values). 
Table 11. Statistics indocators of path relationship between variables.

\begin{tabular}{|c|c|c|c|c|c|}
\hline Impact Path of Variables & $\begin{array}{c}\text { Original } \\
\text { Sample (O) }\end{array}$ & $\begin{array}{c}\text { Sample } \\
\text { Mean (M) }\end{array}$ & $\begin{array}{c}\text { Standard Deviation } \\
\text { (STDEV) }\end{array}$ & $\begin{array}{l}\text { T Statistics } \\
\text { (| O/STDEV|) }\end{array}$ & $p$ Values \\
\hline Intention $\rightarrow$ ProEnv Behavior & 0.15 & 0.15 & 0.04 & 3.28 & 0.00 \\
\hline Attitude $\rightarrow$ Intention & 0.54 & 0.54 & 0.03 & 17.41 & 0.00 \\
\hline Awareness $\rightarrow$ ProEnv Behavior & 0.25 & 0.25 & 0.02 & 8.61 & 0.00 \\
\hline Norm $\rightarrow$ Attitude & 0.33 & 0.33 & 0.03 & 9.57 & 0.00 \\
\hline Norm $\rightarrow$ Awareness & 0.25 & 0.25 & 0.03 & 6.64 & 0.00 \\
\hline Norm $\rightarrow$ Intention & 0.32 & 0.32 & 0.03 & 8.77 & 0.00 \\
\hline Norm $\rightarrow$ ProEnv Behavior & 0.17 & 0.17 & 0.05 & 3.51 & 0.00 \\
\hline Descriptive Norm $\rightarrow$ Norm & 0.70 & 0.70 & 0.01 & 56.61 & 0.00 \\
\hline Social Norm $\rightarrow$ Norm & 0.39 & 0.39 & 0.01 & 28.17 & 0.00 \\
\hline
\end{tabular}

In addition to directly or indirectly examining the effect of numerous latent variables, the structural model is given in this article. Table 12 shows many routes of the link between one latent variable and other latent variables indirectly. It can be explained using one or more mediating factors. For example, the norm influences the intention variable indirectly through the attitude variable inline (1) with a t-statistic value of 8.19 higher than the crucial value of $2.00(p=0.00)$. This meant that norms could change intention through attitude. Table 12 also describes a series of steps that lead to pro-environmental behavior (ProEnv Behavior). Independent variables of norm and attitude can affect pro-environmental behavior through intervening variables. For example, norm can significantly impact proenvironmental behavior through awareness $(t=6.31, p=0.00)$. Attitude can considerably improve behavior through the mediating intention variable $(t=3.31, p=00)$. Finally, the norm is a substantial predictor variable of pro-environmental behavior through attitudeintention ( $t=3.22, p=0.00)$. Intention plays a substantial role in mediating the relationship between norms and pro-environmental behavior, with a t-value of $3.11(p=0.00)$.

Table 12. Indirect influence statistics values of the latent variables.

\begin{tabular}{|c|c|c|c|c|c|}
\hline Indirect Path & $\begin{array}{c}\text { Original } \\
\text { Sample (O) }\end{array}$ & $\begin{array}{c}\text { Sample } \\
\text { Mean (M) }\end{array}$ & $\begin{array}{c}\text { Standard Deviation } \\
\text { (STDEV) }\end{array}$ & $\begin{array}{l}\text { T Statistics } \\
\text { (|O/STDEVI) }\end{array}$ & $p$ Values \\
\hline Norm $\rightarrow$ Attitude $\rightarrow$ Intention & 0.18 & 0.18 & 0.02 & 8.19 & 0.00 \\
\hline Norm $\rightarrow$ Awareness $\rightarrow$ ProEnv_Behavior & 0.06 & 0.06 & 0.01 & 6.31 & 0.00 \\
\hline Attitude $\rightarrow$ Intention $\rightarrow$ ProEnv Behavior & 0.09 & 0.09 & 0.03 & 3.31 & 0.00 \\
\hline Norm $\rightarrow$ Attitude $\rightarrow$ Intention $\rightarrow$ ProEnv_Behavior & 0.03 & 0.03 & 0.01 & 3.22 & 0.00 \\
\hline Norm $\rightarrow$ Intention $\rightarrow$ ProEnv Behavior & 0.05 & 0.05 & 0.02 & 3.11 & 0.00 \\
\hline
\end{tabular}

\section{Discussion}

According to the results, we know the impact of societal norms on consumer attitudes and awareness of the environmental impact of plastic. Norms influence attitude and awareness positively and vitally. The stronger the social norms in people's environment, the more favorable their views and understanding of the environmental impact of plastic will be. Even though the social norms are presented in the ultimate paragraph, the model shown in Figure 2 confirms these results. These two variables comprise the norm construct, a second-order latent variable in this model. The significance level and the meaning of the coefficient do not adequately explain the impact of these two factors on the norm variable. The norm variable's construct reflects this with unobservable dimensions. This reconstruction aims to present the second-order variable as far as the TPB allows. As in the TPB, norms as single dimensions were reconstructed and positioned as explanatory variables of a person's behavior. The norm is a predictor of intention in the TPB; however, it is only a single-order dimension variable.

The dependent variable is pro-environmental behavior, which is the focus of this study. Pro-environmental behavior is a latent variable made up of consumer behaviors 
such as shopping or eating at restaurants outside of the home and daily activity in the home environment. For example, a person's behavior is displayed when shopping in a store, market, or supermarket by denying or avoiding plastic bags. Meanwhile, eating and drinking from plastic containers, such as plates, bowls, spoons, or glasses, are avoided or refused in restaurants. Daily behavior at home is demonstrated by the act of separating consumable plastic packaging waste from other sorts of materials, as well as the act of recycling and reusing plastic garbage. This is a valid and trustworthy indicator of proenvironmental activity that a consumer engages in regularly. These five-point scales show that the higher the score, the more someone "always" does something, implying more environmentally conscious (pro) behavior. Conversely, someone who rarely or never behaves in one or more of these ways suggests that they are unconcerned about the environment or waste or plastic waste contamination.

The attitude variable is measured in this paper by multiple questions that include a person's agreement with positive or negative comments about pollution and the risks of plastic to the environment. The statements offered to the respondents are closed with five-point scale alternatives. The message includes the following points: protecting the environment from plastic pollution is a wise thing to do; being responsible; caring for the earth; participating in the earth's survival; being useful for the future; receiving life benefits; being concerned about the world's plastic pollution situation. According to the data analysis, the minimum loading was for "worried about the issue of plastic pollution in the globe", and the maximum loading was for "Managing plastic trash, activities that help prevent and protect the earth from pollution". The manufacturer with the lowest loading is responsible for items relating to the dangers of plastic pollution. Furthermore, people should be aware that plastic is a medium that can create sickness or produce compounds that are hazardous to the human body, such as respiratory irritation, carcinogens, and dangerous gases. There is no awareness variable as a direct or indirect explanation of behavior in the TPB.

Several studies have discovered that attitudes and awareness are two factors that can influence intentions or action [25-27]. As a result, it is reasonable to suppose that someone's awareness of something and their awareness of the hazards or rewards fosters an attitude toward the object. As a result, it affects their desire to do something and, ultimately, act, referred to as behavior. This study supports previous research while also demonstrating the impact of awareness on attitudes, intentions, and actions. It also shows that the TPB may be expanded by adding more variables, and the results remain consistent [52]. A person's understanding of the risks of plastic, such as irritation of the respiratory system, carcinogenicity, and hazardous gases, will stimulate the establishment of a positive attitude in this study. The mindset that emerges will motivate someone to minimize suffering or avoid the risk of plastic harm. Finally, children learn to behave responsibly and make wise decisions about the plastic packaging they utilize for the products they consume. They will occasionally refuse or not use plastic containers in restaurants or food outlets.

The TPB is a theoretical framework that has been used in various studies, including those on pro-environmental behavior. The theory's basic structure states that the intention variable explains a person's conduct. Meanwhile, the attitude toward the object of activity and standards determines the intention [11]. The use of intention as an intermediary variable hypothesizes that one's beliefs influence pro-environmental conduct and social norms in one's surroundings. Several similar studies established visitors' intentions to visit eco-friendly sites and to consume single-use plastic bags as the main drivers of pro-environmental behavior, suggesting that the theory may explain current occurrences [17-19]. From this standpoint, it is reasonable to conclude that the findings of this study contribute significantly to the TPB, particularly in the area of pro-environmental behavior. The behavior in question concerns being cautious and prudent regarding expired plastic product packaging.

The intention is the state of being prepared to accomplish something in the future. The intention variable was assessed in this study using six valid indicators, including 
will handle plastic better in the future, sort plastic with others, dispose of it in the proper location, reuse, and not litter. According to the TPB, attitudes and norms will appear to trigger a person's intention. In addition, intention acts as a link between attitudes, norms, and behavior. The study's findings suggest that norms indirectly influence proenvironmental behavior through intention. The descriptive and subjective social norms that exist in a person's environment will support the establishment of a person's intention to act in line with anticipated conduct. In some cases, and under particular circumstances, a person's intentions come before their pro-environmental conduct. The encouragement of the norms around a person influences their intentions [30,62]. The norm variable was created as a second-order latent variable in this study. The idea is to determine how each dimension contributes to the overall picture. In the TPB, norms are made up of just one order. The second-order reconstruction of the norm dimension is meant to evaluate the TPB's durability.

In this study, descriptive and social norms were used to create norms. The first dimension refers to the people and organizations closest to a person who provide information, reinforcement, and even written or unwritten laws for dealing with plastic garbage. The family and the lowest levels of governance such as the village, sub-district, or district are examples of external parties. There are higher levels of government, such as the province and the state. The contribution weight of items connected to "family education" is the lowest. This means that the family's educational function is minor compared to other local and state governments. The role of the family as the closest agent, on the other hand, should ideally contribute as much as or more than other agents.

Meanwhile, social norms, specifically post-consumption plastic management practices followed by the closest social group, ranging from school friends to work friends, office friends, and neighbors, are a significant contributor. The item, "The surrounding community is concerned about plastic pollution", makes this obvious. Meanwhile, when compared to acts, invitations made by the greater community, family, or neighbors, intimate friends' concern about plastic issues has the smallest influence. This finding, along with the findings of earlier studies, provides significant evidence for showing that norms provide a useful and valid core framework [30,31]. Furthermore, the outcomes of this study support the validity of the TPB in understanding current phenomena, as evidenced by earlier research $[11,17-19,51,63]$. Furthermore, the findings of this study add to the field's application of the two theories and can be applied to pro-environmental behavior issues.

\section{Conclusions}

Several conclusions were drawn based on the results of data processing: (1) The variables that are the domain of the TPB, expanded by including the awareness variable and norms constructed to be second order, can predict pro-environmental behavior. (2) Behavioral predictor variables, such as attitudes and norms, can explain environmentally responsible intentions and behaviors by the dangers and impacts of plastic waste product packaging. In addition, awareness is an additional explanatory variable in the behavioral model that shapes intentions and behavior. Finally, awareness as a predictor of intentions and behavior is determined by the norms of the surrounding community and existing institutions.

There are some limitations to this study. First, it was limited to 5 village-level areas out of 83,931 in Indonesia. As a result, the generalizability of the research findings cannot be high. Second, the data for the study were gathered using a questionnaire. The researchers created the tool, which is a series of close-ended questions. Respondents were not given the option of providing responses that went beyond the available options. Third, the target respondents at the research site were not as expected for data collection. Not all residents in the study area, particularly those over 40 years old, were willing to complete the questionnaire. They tended to be represented by their children who were still in school or college, which is clear from the relatively large number of respondents in the group with student status. 
As a starting point for future research, the institutional theory might be used. As a next step, researchers, practitioners, and environmentalists can be advised on the following findings: (1) Environmental pollution caused by plastic trash, particularly post-consumption product packaging, can be reduced by raising awareness and encouraging people to act wisely and responsibly when using plastic product packaging. Establishing written or unwritten values in the target environment, such as family, living environment, offices, and the greater administrative area of government, helps to grow and develop awareness and attitudes. (2) For future studies, researchers could expand on a specific theory, in this case, the TPB; adding one variable or reconstructing the studied variable's structure can produce a more meaningful study. For example, the category for norms could be expanded to include not only social and descriptive norms.

Author Contributions: First author W.W.: designing research plans, compiling literature reviews, developing instruments, controlling data collection, processing and analyzing data, drafting manuscripts, submitting, and responding to reviewers. Co-authors A.P., V.P.P., S.N.A. and I.M.: controlling the data collection process, preparing data processing and analysis, compiling and reviewing draft manuscripts. All authors have read and agreed to the published version of the manuscript.

Funding: This study is funded by a University of Muhammadiyah Malang research grant to develop doctoral scientific works and lecturers' professional certification funds for 2021.

Institutional Review Board Statement: Ethical review and approval were waived for this study due to low risk, due to no impact on humans as respondents.

Informed Consent Statement: Informed consent was obtained from all subjects involved in the study.

Data Availability Statement: This study did not report any data.

Acknowledgments: We would like to express our gratitude to the enumerators, the University of Muhammadiyah Malang's administration, and the Dean of the Faculty of Economics and Business for their assistance, collaboration, and support in conducting this study.

Conflicts of Interest: The authors declare no conflict of interest.

\section{References}

1. Zhang, J.; Wu, X.; Guo, H.; Zheng, X.; Mai, B. Pollution of plastic debris and halogenated flame retardants (HFRs) in soil from an abandoned e-waste recycling site: Do plastics contribute to (HFRs) in soil? J. Hazard. Mater. 2020, 410, 124649. [CrossRef] [PubMed]

2. Hahladakis, J.N.; Iacovidou, E.; Gerassimidou, S. Plastic waste in a circular economy. In Plastic Waste and Recycling; Elsevier: Amsterdam, The Netherlands, 2020; pp. 481-512.

3. Thiruketheeswaranathan, S. Usage of Plastic Bags and Environment, Health Hazards: A Study to Access Awareness Level Among a Small Population of Trincomalee Town. Middle East J. Appl. Sci. Technol. (MEJAST) 2019, 2, 42-44.

4. Orset, C.; Barret, N.; Lemaire, A. How consumers of plastic water bottles are responding to environmental policies? Waste Manag. 2017, 61, 13-27. [CrossRef] [PubMed]

5. Grebitus, C.; Roscoe, R.D.; Van Loo, E.J.; Kula, I. Sustainable bottled water: How nudging and Internet Search affect consumers' choices. J. Clean. Prod. 2020, 267, 121930. [CrossRef]

6. Wan Yahaya, W.A.; Abd Hamid, I. Zero-Waste Campaign: Assessment on University Student's Behaviour, Awareness, and Impact on Plastic Products. Malays. J. Soc. Sci. Humanit. (MJSSH) 2020, 5, 24-29.

7. Camacho-Otero, J.; Tunn, V.S.; Chamberlin, L.; Boks, C. Consumers in the circular economy. In Handbook of the Circular Economy; Edward Elgar Publishing: Cheltenham, UK, 2020; pp. 74-87.

8. Confente, I.; Scarpi, D.; Russo, I. Marketing a new generation of bio-plastics products for a circular economy: The role of green self-identity, self-congruity, and perceived value. J. Bus. Res. 2020, 112, 431-439. [CrossRef]

9. Nazareth, M.; Marques, M.; Leite, M.C.; Castro, B. Commercial plastics claiming biodegradable status: Is this also accurate for marine environments? J. Hazard. Mater. 2019, 366, 714-722. [CrossRef]

10. Hammami, M.B.A.; Mohammed, E.Q.; Hashem, A.M.; Al-Khafaji, M.A.; Alqahtani, F.; Alzaabi, S.; Dash, N. Survey on awareness and attitudes of secondary school students regarding plastic pollution: Implications for environmental education and public health in Sharjah city, UAE. Environ. Sci. Pollut. Res. 2017, 24, 20626-20633. [CrossRef]

11. Al-Haziazi, M.; Muthuraman, S. Consumer Environmental Responsibility towards Green Consumption in Sultanate of Oman. Arab. J. Bus. Manag. Rev. Kuwait Chapter 2019, 8, 24-37. [CrossRef]

12. Si, H.; Shi, J.-G.; Tang, D.; Wen, S.; Miao, W.; Duan, K. Application of the Theory of Planned Behavior in Environmental Science: A Comprehensive Bibliometric Analysis. Int. J. Environ. Res. Public Health 2019, 16, 2788. [CrossRef] 
13. Mittal, K.; Agrawal, S. The Assessment and Challenges of Waste Plastic Generation Rate and Status of Revenue Recovery: A Case Study of Mathura-Vrindavan. J. Soc. Sci. 2020, 48, 3531-3541.

14. Aghdam, F.B.; Alamdari, Z.D.; Nadrian, H.; Jafarabadi, M.A.; Dehghanzadeh, R. Personal, Social, and Environmental Factors Associated with the Behavior of Plastic Bag Use among Urban Residents: A Study with Socioecological Approach. Int. J. Prev. Med. 2019, 10, 160. [CrossRef] [PubMed]

15. Zou, J.; Tang, Y.; Qing, P.; Li, H.; Razzaq, A. Donation or Discount: Effect of Promotion Mode on Green Consumption Behavior. Int. J. Environ. Res. Public Health 2021, 18, 1912. [CrossRef]

16. Ajzen, I. The theory of planned behavior. Organ. Behav. Hum. Decis. Processes 1991, 50, 179-211. [CrossRef]

17. Zhang, K. Theory of Planned Behavior: Origins, Development and Future Direction. Int. J. Humanit. Soc. Sci. Invent. (IJHSSI) 2018, 7, 76-83.

18. Young, H.M.; Lierman, L.; Powell-Cope, G.; Kasprzyk, D.; Benoliel, J.Q. Operationalizing the theory of planned behavior. Res. Nurs. Health 1991, 14, 137-144. [CrossRef] [PubMed]

19. Yuriev, A.; Dahmen, M.; Paillé, P.; Boiral, O.; Guillaumie, L. Pro-environmental behaviors through the lens of the theory of planned behavior: A scoping review. Resour. Conserv. Recycl. 2020, 155, 104660. [CrossRef]

20. Ahmad, W.; Kim, W.G.; Anwer, Z.; Zhuang, W. Schwartz personal values, theory of planned behavior and environmental consciousness: How tourists' visiting intentions towards eco-friendly destinations are shaped? J. Bus. Res. 2020, 110, $228-236$. [CrossRef]

21. Vina, D. The Application of Theory of Planned Behavior in Single-Use Plastic Bags Consumption in Bandung. J. Glob. Bus. Soc. Entrep. (GBSE) 2020, 6, 124-137.

22. Wang, J.; Wang, S.; Wang, Y.; Li, J.; Zhao, D. Extending the theory of planned behavior to understand consumers' intentions to visit green hotels in the Chinese context. Int. J. Contemp. Hosp. Manag. 2018, 30, 2810-2825. [CrossRef]

23. Shin, Y.H.; Im, J.; Jung, S.E.; Severt, K. The theory of planned behavior and the norm activation model approach to consumer behavior regarding organic menus. Int. J. Hosp. Manag. 2018, 69, 21-29. [CrossRef]

24. López-Mosquera, N.; Sánchez, M. Theory of Planned Behavior and the Value-Belief-Norm Theory explaining willingness to pay for a suburban park. J. Environ. Manag. 2012, 113, 251-262. [CrossRef]

25. Li, J.; Zuo, J.; Cai, H.; Zillante, G. Construction waste reduction behavior of contractor employees: An extended theory of planned behavior model approach. J. Clean. Prod. 2017, 172, 1399-1408. [CrossRef]

26. Savari, M.; Gharechaee, H. Application of the extended theory of planned behavior to predict Iranian farmers' intention for safe use of chemical fertilizers. J. Clean. Prod. 2020, 263, 121512. [CrossRef]

27. Firdaus, F.E. Examining the Youths Intention to Plastic Bags; A Recommendation to Creating Sustainability Environment in Jakarta. Int. J. Environ. Sci. 2020, 5, 207-2012.

28. Verma, V.; Chandra, B. An application of theory of planned behavior to predict young Indian consumers' green hotel visit intention. J. Clean. Prod. 2018, 172, 1152-1162. [CrossRef]

29. Chauhan, R.S. Environmental Awareness and Environmental Attitude of In-service Secondary School Teachers (With special Reference of Uttarakhand State). Mukt Shabd J. 2020, 9, 87-101.

30. Ghazvini, S.A.M.; Timothy, D.J.; Sarmento, J. Environmental concerns and attitudes of tourists towards national park uses and services. J. Outdoor Recreat. Tour. 2020, 31, 100296. [CrossRef]

31. Praneetham, C.; Phrommana, J.; Kadroon, T. Awareness, Attitudes, and Behaviors towards the Environment and the Management of Historical Tourism Resources of Muang Wiang Sa Community. Chophayom J. 2018, 29, 11-24.

32. Rogayan, D.; El Elyionna, E.D.N. Environmental Awareness and Practices of Science Students: Input for Ecological Management Plan. Int. Electron. J. Environ. Educ. 2019, 9, 106-119.

33. Rezaei-Moghaddam, K.; Vatankhah, N.; Ajili, A. Adoption of pro-environmental behaviors among farmers: Application of Value-Belief-Norm theory. Chem. Biol. Technol. Agric. 2020, 7, 1-15. [CrossRef]

34. Karimi, S. Pro-Environmental Behaviours among Agricultural Students: An Examination of the Value-Belief-Norm Theory. J. Agric. Sci. Technol. 2019, 21, 249-263. [CrossRef]

35. Sharma, R.; Gupta, A. Pro-environmental behaviour among tourists visiting national parks: Application of value-belief-norm theory in an emerging economy context. Asia Pac. J. Tour. Res. 2020, 25, 829-840. [CrossRef]

36. Li, Q.; Wu, M. Tourists' pro-environmental behaviour in travel destinations: Benchmarking the power of social interaction and individual attitude. J. Sustain. Tour. 2020, 28, 1371-1389. [CrossRef]

37. Gupta, A.; Sharma, R. Pro-environmental behaviour of adventure tourists: An applicability of value belief norm theory. Tourism 2019, 67, 253-267.

38. Kikuchi-Uehara, E.; Nakatani, J.; Hirao, M. Analysis of factors influencing consumers' proenvironmental behavior based on life cycle thinking. Part I: Effect of environmental awareness and trust in environmental information on product choice. J. Clean. Prod. 2016, 117, 10-18. [CrossRef]

39. Chwialkowska, A.; Bhatti, W.A.; Glowik, M. The influence of cultural values on pro-environmental behavior. J. Clean. Prod. 2020, 268, 122305. [CrossRef]

40. Farrow, K.; Grolleau, G.; Ibanez, L. Social Norms and Pro-environmental Behavior: A Review of the Evidence. Ecol. Econ. 2017, 140, 1-13. [CrossRef] 
41. Fu, L.; Sun, Z.; Zha, L.; Liu, F.; He, L.; Sun, X.; Jing, X. Environmental awareness and pro-environmental behavior within China's road freight transportation industry: Moderating role of perceived policy effectiveness. J. Clean. Prod. 2019, 252, 119796. [CrossRef]

42. Gautam, V. Examining environmental friendly behaviors of tourists towards sustainable development. J. Environ. Manag. 2020, 276, 111292. [CrossRef]

43. Kim, M.J.; Hall, C.M.; Kim, D.-K. Predicting environmentally friendly eating out behavior by value-attitude-behavior theory: Does being vegetarian reduce food waste? J. Sustain. Tour. 2019, 28, 797-815. [CrossRef]

44. Sun, Y.; Liu, N.; Zhao, M. Factors and mechanisms affecting green consumption in China: A multilevel analysis. J. Clean. Prod. 2019, 209, 481-493. [CrossRef]

45. Liu, A.; Ma, E.; Qu, H.; Ryan, B. Daily green behavior as an antecedent and a moderator for visitors' pro-environmental behaviors. J. Sustain. Tour. 2020, 28, 1390-1408. [CrossRef]

46. Tuger, A.T. Application of Value-Belief-Norm Theory to Responsible Post Consumption Behaviors: Recycling and Reuse. In Proceedings of the International Congress of the New Approaches and Technologies for Sustainable Development, Isparta, Turkey, 21-24 September 2017.

47. Bohner, G.; Dickel, N. Attitudes and Attitude Change. Annu. Rev. Psychol. 2011, 62, 391-417. [CrossRef] [PubMed]

48. Ajzen, I. Consumer attitudes and behavior: The theory of planned behavior applied to food consumption decisions. Ital. Rev. Agric. Econ. 2016, 70, 121-138. [CrossRef]

49. Saleki, Z.S.; Seyedsaleki, S.M. The Main Factors Influencing Purchase Behaviour of Organic Products in Malaysia. Interdiscip. J. Contemp. Res. Bus. 2012, 4, 98-116.

50. Hackman, C.; Knowlden, A. Theory of reasoned action and theory of planned behavior-based dietary interventions in adolescents and young adults: A systematic review. Adolesc. Health Med. Ther. 2014, 5, 101-114. [CrossRef]

51. Alam, S.S.; Sayuti, N.M. Applying the Theory of Planned Behavior (TPB) inhalalfood purchasing. Int. J. Commer. Manag. 2011, 21, 8-20. [CrossRef]

52. Paul, J.; Modi, A.; Patel, J. Predicting green product consumption using theory of planned behavior and reasoned action. J. Retail. Consum. Serv. 2016, 29, 123-134. [CrossRef]

53. Record, R.A.; Harrington, N.G.; Helme, D.W.; Savage, M.W. Using the Theory of Planned Behavior to Guide Focus Group Development of Messages Aimed at Increasing Compliance with a Tobacco-Free Policy. Am. J. Health Promot. 2017, 32, 143-152. [CrossRef] [PubMed]

54. Wang, Y.; Liang, J.; Yang, J.; Ma, X.; Li, X.; Wu, J.; Yang, G.; Ren, G.; Feng, Y. Analysis of the environmental behavior of farmers for non-point source pollution control and management: An integration of the theory of planned behavior and the protection motivation theory. J. Environ. Manag. 2019, 237, 15-23. [CrossRef]

55. Nyborg, K.; Andries, J.M.; Dannenberg, A.; Lindahl, T.; Schill, C.; Schlüter, M.; Neil Adger, W.; Arrow, K.J.; Barrett, S.; Carpenter, S.; et al. Social norms as solutions. Policies may influence large-scale behavioral tipping. Science 2016, $354,42-43$. [CrossRef] [PubMed]

56. Bamberg, S.; Rollin, P.; Schulte, M. Local mobility culture as injunctive normative beliefs-A theoretical approach and a related measurement instrument. J. Environ. Psychol. 2020, 71, 101465. [CrossRef]

57. Reynolds-Tylus, T.; Lukacena, K.M.; Quick, B.L. An application of the theory of normative social behavior to bystander intervention for sexual assault. J. Am. Coll. Health 2018, 67, 551-559. [CrossRef] [PubMed]

58. Byron, M.J.; Cohen, J.E.; Frattaroli, S.; Gittelsohn, J.; Jernigan, D.H. Using the theory of normative social behavior to understand compliance with a smoke-free law in a middle-income country. Health Educ. Res. 2016, 31, 738-748. [CrossRef]

59. Borg, K.; Curtis, J.; Lindsay, J. Social norms and plastic avoidance: Testing the theory of normative social behaviour on an environmental behaviour. J. Consum. Behav. 2020, 19, 594-607. [CrossRef]

60. Collado, S.; Evans, G.W. Outcome expectancy: A key factor to understanding childhood exposure to nature and children's pro-environmental behavior. J. Environ. Psychol. 2019, 61, 30-36. [CrossRef]

61. Kautish, P.; Paul, J.; Sharma, R. The moderating influence of environmental consciousness and recycling intentions on green purchase behavior. J. Clean. Prod. 2019, 228, 1425-1436. [CrossRef]

62. Megeirhi, H.A.; Woosnam, K.M.; Ribeiro, M.A.; Ramkissoone, H.R.; Denley, T.J. Employing a value-belief-norm framework to gauge Carthage residents' intentions to support sustainable cultural heritage tourism. J. Sustain. Tour. 2020, 28, 1351-1370. [CrossRef]

63. Olya, H.G.T.; Akhshik, A. Tackling the Complexity of the Pro-environmental Behavior Intentions of Visitors to Turtle Sites. J. Travel Res. 2018, 58, 313-332. [CrossRef] 